\title{
Respon Pertumbuhan dan Hasil Tanaman Terung terhadap Pemberian Dosis Pupuk Kandang Kotoran Itik pada Lahan Rawa Lebak
}

\section{(Growth Response And Yield of Eggplan to Ducks Manure Dosages Application on Lebak Wetlands)}

\author{
Fahriadi $^{1)}$ \& Mahdiannoor $^{2}$ \\ Program Studi Agroteknologi, Sekolah Tinggi Ilmu Pertanian Amuntai \\ fahri@yahoo.com \\ mahdi_186@yahoo.com
}

\begin{abstract}
ABSTRAK
Tanaman terung dapat tumbuh di semua jenis lahan yang digunakan untuk budidaya pertanian, tetapi kurang baik jika ditanam di lahan rawa karena suplai nutrisi yang buruk sehingga perlu perlakuan khusus untuk memperbaikinya dengan cara pemberian pupuk organik seperti pupuk kandang kotoran itik. Pemberian pupuk organik dapat memperbaiki sifat fisik, kimia dan biologi pada tanah rawa lebak Penelitian ini bertujuan untuk (i) mengetahui respon pertumbuhan dan hasil tanaman terung terhadap pemberian dosis pupuk kandang kotoran itik pada lahan rawa lebak, (ii) menentukan dosis terbaik pemberian pupuk kandang kotoran itik terhadap pertumbuhan dan hasil tanaman terung di lahan rawa lebak. Penelitian ini dilakukan di Desa Rantawan Kecamatan Amuntai Tengah, Kabupaten Hulu Sungai Utara, dari bulan Mei - Agustus 2010, menggunakan Rancangan Acak Kelompok (RAK), dengan 5 perlakuan dan 4 ulangan, sehingga terdapat 20 satuan percobaan. Perlakuan yang diuji adalah dosis pupuk kandang kotoran itik sebanyak 5 taraf yaitu $t_{0}=0$ t ha ${ }^{-1}, t_{1}=$

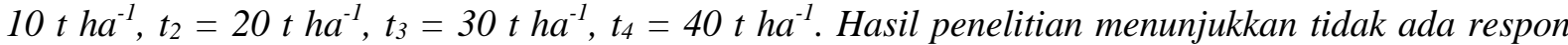
tinggi tanaman umur 14 dan 21 hari setelah tanam (HST), respon nyata jumlah daun umur 14 HST, dan respon sangat nyata jumlah daun umur 14, 21 dan 35 HST terhadap pemberian dosis pupuk kandang kotoran itik. Dosis terbaik pemberian pupuk kandang kotoran itik untuk pertumbuhan dan hasil tanaman terung di lahan rawa lebak adalah $t_{1}$ yaitu 10 tha- ${ }^{-1}$
\end{abstract}

Kata kunci: Terung, pupuk kandang, kotoran itik, lahan, lebak.

\section{ABSTRACT}

Eggplant plants can grow on all types of land used for agricultural cultivation, but are not good if planted in lowland because of poor supply of nutrients so that special treatment is needed to improve it by giving duck manure so that the growth and yield of eggplant plants can be optimal. Giving organic fertilizer can improve physical, chemical and biological properties of lowland soil. This study aims to (i) determine the growth response and yield of eggplant plants on dosing duck manure dosages application on lebak lowland, (ii) determine the best dosage of duck manure on the growth and yield of eggplant on lebak lowland. This research was conducted in Rantawan Village, Amuntai Tengah District, Hulu Sungai Utara Regency, from May - August 2010, using a Randomized Block Design (RBD), with 5 treatments and 4 replications, so that there were 20 experimental unit. The treatments tested were 5 doses of duck manure, $t_{0}=0 \mathrm{tha}^{-1}, t_{1}=10 \mathrm{tha}^{-1}, t_{2}=20 \mathrm{tha}^{-1}, t_{3}=30 \mathrm{t}$ $h a^{-1}, t_{4}=40 t h a^{-1}$. The results showed no response to plant height aged 14 and 21 days after planting $(D A P)$, the real response of the number of leaves aged $14 D A P$, and the response was very significant the number of leaves aged 14,21 and 35 DAP due to the application of duck manure dung fertilizer. The best dosage of duck manure for growth and eggplant yield on lebak wetland is $t_{1}$, which is $10 t$ $h a^{-1}$.

Keywords: Eggplant, dung, ducks manure, land, lebak wetland 


\section{PENDAHULUAN}

Terung (Solanum melongena L.) termasuk golongan sayuran buah. Sayuran ini banyak digemari karena selain rasanya enak dan harganya relatif murah, kandungan gizinya pun cukup lengkap yaitu protein, lemak, karbohidrat, vitamin A, vitamin B, vitamin C, kalium, fosfor dan zat besi (Soetasad dan Muryanti, 1999).

Kabupaten Hulu Sungai Utara memiliki luas rawa lebak sekitar 89.270 $\mathrm{km}^{2}$,tetapi lahan yang belum dimanfaatkan masih cukup luas sehingga peluang untuk berbagai pemanfaatan terutama budidaya sayuran di lahan rawa lebak di masa yang akan datang masih sangat besar (Bappeda Kab. HSU, 2010).

Hal yang menjadi permasalahan pada lahan tersebut adalah sifat kimia yaitu peningkatan kelarutan $\mathrm{Al}, \mathrm{Fe}, \mathrm{Mn}$ dan $\mathrm{Cu}$ yang dapat meracuni tanaman bila tersedia banyak. Sifat fisik tanah yang kurang menguntungkan karena rawa lebak memiliki tekstur liat, tidak gembur dan pori tanah yang sangat kecil sehingga mikroorganisme sulit untuk hidup (Noor, 2004). Pemberian bahan organik yang berasal dari sampah organik, kotoran ternak, jerami padi, abu sekam padi atau gulma yang sudah membusuk berperan besar dalam mengurangi kelarutan unsurunsur beracun, sumber hara bagi tanaman dan sumber energi dalam menunjang aktifitas mikroorganisme tanah (Syahruzad, 1987).

Peningkatan produksi tanaman pada lahan rawa lebak dapat dicapai bila dilakukan perbaikan sifat tanah yaitu dengan melakukan pemberian pupuk organik seperti pupuk kandang kotoran itik. Kabupaten Hulu Sungai Utara merupakan daerah dengan ternak itik yang lebih dikenal dengan sebutan itik alabio. Sebagian besar masyarakatnya beternak itik sehingga kotoran ternak itik dapat dimanfaatkan untuk pembuatan pupuk kandang.

Penelitian ini bertujuan mengetahui respon pertumbuhan dan hasil tanaman terung terhadap pemberian dosis pupuk kandang kotoran itik pada lahan rawa lebak, (ii) mendapatkan dosis terbaik pemberian pupuk kandang kotoran itik terhadap pertumbuhan dan hasil tanaman terung pada lahan rawa lebak.

\section{METODE PENELITIAN}

\section{Tempat dan Waktu Penelitian}

Penelitian di laksanakan pada bulan Mei - Agustus 2010 di Desa Rantawan Kecamatan Amuntai Tengah Kabupaten Hulu Sungai Utara Propinsi Kalimantan Selatan.

\section{Bahan dan Alat}

Bahan yang digunakan pada penelitian ini adalah media tanam adalah lahan rawa lebak. Benih tanaman terung varietas Mustang $F_{1}$, pupuk kandang kotoran itik sebagai perlakuan, air untuk menyiram tanaman terung, pestisida yang digunakan adalah Furadan dan Matador. Alat yang digunakan antara lain cangkul, parang, gembor, hand sprayer, meteran, timbangan, kamera dan alat tulis.

\section{Rancangan Percobaan}

Penelitian ini merupakan percobaan yang dilaksanakan di lapangan, dengan menggunakan Rancangan Acak Kelompok (RAK) faktor tunggal. Pengelompokan yang dilakukan berdasarkan tinggi bibit tanaman terung. Faktor yang diteliti adalah dosis pupuk kandang kotoran itik (T) sebanyak 5 taraf, yang terdiri dari: $\mathrm{t}_{0}=$ 0 t.ha ${ }^{-1}=0 \quad$ g.petak ${ }^{-1}, t_{1}=10$ t.ha ${ }^{-1}=$ 5800 g.petak ${ }^{-1}, \quad t_{2}=20$ t.ha $^{-1}=11600$ g.petak ${ }^{-1}, t_{3}=30$ t.ha $a^{-1}=17400$ g.petak ${ }^{-}$ ${ }^{1}$ dan $t_{4}=40$ t.ha ${ }^{-1}=23200$ g.petak ${ }^{-1}$ dengan 4 ulangan/kelompok. Dengan demikian terdapat 20 satuan percobaan dan 2 tanaman sampel. Pengamatan yang dilakukan adalah : tinggi tanaman dan jumlah daun di hitung pada umur 14, 21, 28 dan 35 hari setelah tanam (HST); jumlah cabang, jumlah cabang yang dihitung adalah cabang produktif dihitung saat panen; jumlah buah per tanaman, 
jumlah buah pertanaman dihitung pada saat panen.

Data yang diperoleh dilakukan uji kehomogenan ragam Bartlet. Untuk mengetahui pengaruh perlakuan terhadap peubah yang diamati dilakukan analisis ragam menggunakan uji $\mathrm{F}$ pada taraf nyata $5 \%$ atau sangat nyata $1 \%$. Jika $\mathrm{F}$ hitung $>$ $\mathrm{F}$ tabel $5 \%$ dan $1 \%$ berarti perlakuan dosis pupuk kandang kotoran itik memberikan respon nyata atau sangat nyata pada setiap peubah yang diamati, kemudian dilanjutkan dengan uji beda nilai tengah menggunakan uji jarak ganda Duncan (DMRT) pada taraf uji 5\%.

\section{HASIL DAN PEMBAHASAN}

\section{Hasil}

\section{Tinggi Tanaman}

Berdasarkan analisis ragam diketahui bahwa terdapat respon nyata pada tinggi tanaman umur 14 dan 21 HST dan respon sangat nyata pada tinggi tanaman umur 28 dan 35 HST terhadap pemberian perlakuan dosis pupuk kandang kotoran itik. Hasil uji beda nilai tengah tinggi tanaman pada umur 14, 21, 28 dan 35 HST dapat dilihat pada Tabel 1.

Berdasarkan hasil uji beda nilai tengah terlihat rata-rata tinggi tanaman tertinggi pada umur 14 HST pada perlakuan $\mathrm{t}_{4}$ yaitu $1,26 \mathrm{~cm}$ yang tidak berbeda dengan perlakuan $t_{1}, t_{2}, t_{3}$ dan berbeda dengan $t_{0}$, perlakuan terbaik pada umur 14 HST adalah $\mathrm{t}_{1}$. Pada umur $21 \mathrm{HST}$ tinggi tanaman tertinggi pada perlakuan $\mathrm{t}_{4}$ yaitu $22,37 \mathrm{~cm}$, yang tidak berbeda dengan perlakuan $t_{1}, t_{2}$, dan $t_{3}$ tetapi berbeda dengan perlakuan $t_{0}$, perlakuan terbaik pada umur 21 HST adalah perlakuan $t_{1}$. Pada Umur 28 HST tinggi tanaman tertinggi pada perlakuan $t_{4}$ yaitu $26,75 \mathrm{~cm}$ yang tidak berbeda dengan perlakuan $\mathrm{t}_{1}, \mathrm{t}_{2}$ dan $t_{3}$ tetapi berbeda dengan perlakuan $t_{0}$, perlakuan terbaik pada umur 28 HST adalah perlakuan $t_{1}$. Pada umur 35 HST tinggi tanaman tertinggi pada perlakuan $\mathrm{t}_{4}$ yaitu $30,50 \mathrm{~cm}$ yang tidak berbeda dengan perlakuan $t_{2}$ dan $t_{3}$ tetapi berbeda dengan perlakuan $t_{0}$ dan $t_{1}$, perlakuan terbaik pada umur 28 HST adalah $\mathrm{t}_{1}$.

Tabel 1. Hasil uji beda nilai tengah tinggi tanaman terung umur 14, 21, 28 dan 35 HST

\begin{tabular}{ccccc}
\hline Perlakuan & \multicolumn{4}{c}{ Rata-rata tinggi tanaman $(\mathrm{cm})$} \\
\cline { 2 - 5 } & $14 \mathrm{HST}$ & $21 \mathrm{HST}$ & $28 \mathrm{HST}$ & $35 \mathrm{HST}$ \\
\hline $\mathrm{t}_{0}$ & $1,10^{\mathrm{a}}$ & $14,87^{\mathrm{a}}$ & $17,75^{\mathrm{a}}$ & $21,75^{\mathrm{a}}$ \\
$\mathrm{t}_{1}$ & $1,22^{\mathrm{b}}$ & $19,87^{\mathrm{b}}$ & $24,62^{\mathrm{b}}$ & $27,00^{\mathrm{b}}$ \\
$\mathrm{t}_{2}$ & $1,23^{\mathrm{b}}$ & $20,50^{\mathrm{b}}$ & $26,00^{\mathrm{b}}$ & $29,50^{\mathrm{bc}}$ \\
$\mathrm{t}_{3}$ & $1,22^{\mathrm{b}}$ & $20,37^{\mathrm{b}}$ & $25,00^{\mathrm{b}}$ & $29,50^{\mathrm{bc}}$ \\
$\mathrm{t}_{4}$ & $1,26^{\mathrm{b}}$ & $22,37^{\mathrm{b}}$ & $26,75^{\mathrm{b}}$ & $30,50^{\mathrm{c}}$ \\
\hline
\end{tabular}

Keterangan: Angka yang diikuti huruf yang sama pada kolom yang sama tidak berbeda menurut DMRT pada taraf uji 5\%

\section{Jumlah Daun}

Berdasarkan analisis ragam diketahui bahwa tidak ada respon jumlah daun umur 14 HST dan respon sangat nyata jumlah daun umur 21, 28 dan 35 HST terhadap pemberian perlakuan pupuk kandang kotoran itik. Hasil uji beda nilai tengah jumlah daun pada umur 21, 28 dan 35 HST dapat dilihat pada Tabel 2. Berdasarkan hasil uji beda nilai tengah terlihat rata-rata jumlah daun terbanyak pada umur 21 HST adalah perlakuan $\mathrm{t}_{4}$ yaitu 6,25 helai yang tidak berbeda dengan perlakuan $t_{3}$ tetapi berbeda dengan perlakuan $t_{0}, t_{1}$ dan $t_{2}$ perlakuan terbaik pada umur 21 HST adalah perlakuan $t_{3}$. Pada umur 28 HST rata-rata jumlah daun terbanyak pada perlakuan $t_{4}$ yaitu 7,25 helai yang tidak berbeda dengan perlakuan $t_{2}$ dan $t_{3}$ tetapi berbeda dengan perlakuan $t_{0}$ dan $t_{1}$ dan 
Rawa Sains: Jurnal Sains STIPER Amuntai, Desember 2011, 1(1), 1-6.

perlakuan terbaik pada umur 28 HST adalah perlakuan $t_{2}$. Pada umur 35 HST rata-rata jumlah daun terbanyak pada perlakuan $t_{2}$ dan $t_{3}$ yaitu 7,25 helai yang tidak berbeda dengan perlakuan $t_{4}$ tetapi berbeda dengan perlakuan $t_{0}$ dan $t_{1}$ dan perlakuan terbaik pada umur 35 HST adalah perlakuan $\mathrm{t}_{2}$.

Tabel 2. Hasil uji beda nilai tengah jumlah daun umur 21, 28 dan 35 HST

\begin{tabular}{cccc}
\hline Perlakuan & \multicolumn{3}{c}{ Rata-rata jumlah daun (helai) } \\
\cline { 2 - 4 } & $21 \mathrm{HST}$ & $28 \mathrm{HST}$ & $35 \mathrm{HST}$ \\
\hline $\mathrm{t}_{0}$ & $3,75^{\mathrm{a}}$ & $4,75^{\mathrm{a}}$ & $5,25^{\mathrm{a}}$ \\
$\mathrm{t}_{1}$ & $5,25^{\mathrm{b}}$ & $5,75^{\mathrm{b}}$ & $6,25^{\mathrm{b}}$ \\
$\mathrm{t}_{2}$ & $5,25^{\mathrm{b}}$ & $6,50^{\mathrm{bc}}$ & $7,25^{\mathrm{c}}$ \\
$\mathrm{t}_{3}$ & $5,75^{\mathrm{bc}}$ & $6,50^{\mathrm{bc}}$ & $7,25^{\mathrm{c}}$ \\
$\mathrm{t}_{4}$ & $6,25^{\mathrm{c}}$ & $7,25^{\mathrm{c}}$ & $7,00^{\mathrm{bc}}$
\end{tabular}

Keterangan : Angka yang diikuti huruf yang sama pada kolom yang sama tidak berbeda menurut DMRT pada taraf uji 5\%

\section{Jumlah Cabang}

Dari hasil analisis ragam diketahui bahwa tidak ada respon jumlah cabang tanaman terung terhadap pemberian pupuk kandang kotoran itik. Dari hasil pengamatan jumlah cabang menunjukkan jumlah cabang terbanyak pada perlakuan $\mathrm{t}_{4}$ yaitu 18 buah, dan nilai terendah pada perlakuan $\mathrm{t}_{0}$ yaitu 10 buah.

\section{Jumlah Buah Pertanaman}

Berdasarkan analisis ragam diketahui bahwa terdapat respon jumlah buah pertanaman terhadap pemberian perlakuan dosis pupuk kandang kotoran itik. Hasil uji beda nilai tengah jumlah buah pertanaman dapat dilihat pada Tabel 3. Berdasarkan hasil uji beda nilai tengah terlihat jumlah buah terbanyak pada perlakuan $\mathrm{t}_{4}$ yaitu 4,50 buah yang tidak berbeda dengan perlakuan $t_{1}, t_{2}$ dan $t^{3}$ tetapi berbeda dengan perlakuan $t_{0}$.

Tabel 3. Hasil uji beda nilai tengah jumlah buah per tanaman terung

\begin{tabular}{cc}
\hline Perlakuan & Rata-rata jumlah buah per tanaman (buah) \\
\hline $\mathrm{t}_{0}$ & $2,50^{\mathrm{a}}$ \\
$\mathrm{t}_{1}$ & $3,75^{\mathrm{ab}}$ \\
$\mathrm{t}_{2}$ & $3,75^{\mathrm{ab}}$ \\
$\mathrm{t}_{3}$ & $3,25^{\mathrm{ab}}$ \\
$\mathrm{t}_{4}$ & $4,50^{\mathrm{b}}$
\end{tabular}

Keterangan : Angka yang diikuti huruf yang sama pada kolom yang sama tidak berbeda menurut DMRT pada taraf uji 5\%

\section{Pembahasan}

Bervariatifnya hasil yang diperoleh pada peubah pengamatan pertumbuhan maupun hasil tanaman terung menunjukkan responnya terhadap pemberian dosis pupuk kandang kotoran itik dan batas kecukupan tanaman terung untuk keperluan unsur haranya pada perlakuan $\mathrm{t}_{1}$ yaitu 10 t.ha ${ }^{-1}$ atau setara 5800 g.petak ${ }^{-1}$. Di atas dosis tersebut memang masih memberikan peningkatan terhadap semua peubah pengamatan namun peningkatannya tidak drastis. Diatas dosis perlakuan $\mathrm{t}_{1}$ juga tidak memberikan efek yang negatif bagi tanaman karena yang digunakan adalah pupuk organik. 
Perlakuan $\mathrm{t}_{1}$ merupakan perlakuan terbaik dalam percobaan ini adalah dosis yang paling kecil. Pupuk atau bahan organik dalam jumlah sedikit lebih cepat terurai dan tersedia untuk tanaman, sedangkan pupuk atau bahan organik dalam jumlah banyak perlu waktu yang lebih lama untuk terurai dan tersedia bagi tanaman. Pupuk atau bahan organik dalam jumlah sedikit memang lebih cepat terurai dan tersedia bagi tanaman, namun juga cepat habis ketersediaannya. Sebaliknya pupuk atau bahan organik dalam jumlah besar ketersediannya juga akan lebih lama daripada yang sedikit.

Kelebihan pupuk organik adalah mengandung unsur hara makro dan mikro lengkap, tetapi jumlahnya sedikit, dapat memperbaiki struktur tanah, sehingga tanah menjadi gembur, memiliki daya simpan air (water holding capasity) yang tinggi, tanaman lebih tahan terhadap serangan penyakit, meningkatkan aktivitas mikroorganisme tanah yang menguntungkan, memiliki residual effect yang positif, sehingga tanaman yang ditanam pada musim berikutnya tetap bagus pertumbuhan dan produktivitasnya (Lingga, 2001).

Pertumbuhan vegetatif tanaman terung banyak memerlukan unsur-unsur hara yang terkandung pada pupuk kandang kotoran itik terutama unsur N. Pemberian unsur hara $\mathrm{N}$ pada tanah sangat diperlukan untuk menunjang pertumbuhan tanaman terung. Pada penelitian ini berarti unsur $\mathrm{N}$ sebesar $1,00 \%$ yang terkandung pada pupuk kandang kotoran itik mampu memenuhi kebutuhan tanaman terung tersebut. Selain unsur N, unsur P dan K yang terkandung pada pupuk kandang kotoran itik juga berperan penting dalam fase vegetatif tanaman terung. Menurut Suharno (2010), tahap vegetatif tanaman berlangsung mulai dari perkecambahan biji sampai inisiasi. Pada fase vegetatif tanaman, seluruh proses fisiologi hanya ditujukan untuk pembentukan batang, daun, cabang, dan anakan. Pada fase vegetatif ini diperlukan banyak pupuk nitrogen. Menurut Lingga (2001), bahwa nitrogen mempunyai peranan penting dalam merangsang pertumbuhan seperti batang, cabang, daun, dan akar serta sangat penting dalam pembentukan protein, lemak dan senyawa-senyawa yang lain.

Unsur $P$ juga berperan penting sebagai penghasil energi bagi tanaman. Sastrahidayat (2000), menyatakan bahwa bahan organik mampu menghasilkan enzim fosfatase yang dapat mengurai senyawa fosfat menjadi bentuk yang siap diserap untuk akar tanaman. Fosfor yang diserap digunakan tanaman sebagai penghasil energi pembelah sel, sehingga semakin banyak $\mathrm{P}$ yang diambil tanaman maka pembelahan sel, aktivitas pertumbuhan semakin tinggi.

Selain berperan pada fase generatif tanaman, unsur $\mathrm{K}$ juga berperan penting pada fase vegetatif tanaman. Menurut Syaiful (2009), kalium memiliki peranan untuk memperlancar fotosintesa, membantu pembentukan protein dan hidrat arang, sebagai katalisator dalam transformasi tepung, gula dan lemak tanaman, mengeraskan jerami dan bagian kayu dari tanaman, meninggikan daya tahan tanaman terhadap serangan hama, penyakit dan kekeringan, pada tanaman unsur ini terkumpul pada titik tumbuh dan mempercepat pertumbuhan jaringan merismatik.

Selain menyediakan unsur hara, pemberian bahan organik akan memperbaiki sifat fisik tanah sehingga semakin menggemburkan tanah dan kandungan oksigen tanah akan semakin baik, kondisi ini akan meningkatkan pertumbuhan akar tanaman sehingga tanaman semakin banyak mendapatkan makanan dari dalam tanah (Wididana, 1998).

\section{KESIMPULAN}

Tidak ada respon jumlah daun umur 14 HST dan jumlah cabang pertanaman, ada respon nyata tinggi tanaman umur 14 dan 21 HST serta jumlah buah per 
Rawa Sains: Jurnal Sains STIPER Amuntai, Desember 2011, 1(1), 1-6.

tanaman, respon sangat nyata tinggi tanaman umur 28 dan 35 HST serta jumlah daun umur 21, 28, dan 35 HST terhadap pemberian dosis pupuk kandang kotoran itik. Perlakuan terbaik untuk pertumbuhan dan hasil tanaman terung pada lahan rawa lebak yaitu perlakuan $\left(\mathrm{t}_{1}\right)$ dengan dosis $10 \mathrm{t} \mathrm{ha}^{-1}$.

\section{DAFTAR PUSTAKA}

Bappeda Kab. HSU. 2010. Data pokok dan Album peta. Pemerintah Kab. HSU. Amuntai

Noor, M. 2004. Lahan Rawa, Sifat dan Pengelolaan Tanah Bermasalah Sulfat Masam. Raja Grafindo Persada. Surabaya.

Sastrahidayat, I. R. 2000. Aplikasi mikoriza vesikular arbuskula pada berbagai jenis tanaman pertanian di Jawa Timur. Prosiding Seminar Nasional Mikoriza I. Pemanfaatan cendawan mikoriza arbuskula sebagai agen bioteknologi ramah lingkungan dalam meningkatkan produktivitas lahan dibidang kehutanan, perkebunan, dan pertanian di era milenium baru. Kerjasama Asosiasi Mikoriza Indonesia (AMI), Pusat Antar
Universitas (PAU) Bioteknologi Institut Pertanian Bogor, Badan Litbang Kehutanan dan Perkebunan, dan The British Council, Bogor.

Soetasad. A dan Sri Muryanti. 1999. Budidaya Terung Lokal dan Terung Jepang. PT. Penebar Swadaya. Jakarta

Suharno. 2010. Mata Kuliah Serealia. http://www.distan.pemdadiy.go.id/i ndex 2 . php?option=content $\&$ task $=$ view\&i $\mathrm{d}=178 \&$ pop $=1 \&$ page $=0 . \quad$ Diakses tanggal 3 Juli 2010.

Syahruzad, A. 1987. Pengaruh dosis hyponex biru dan jenis media tumbuh terhadap pertumbuhan dan produksi tomat. Skripsi. Fakultas Pertanian UNLAM. Banjarbaru.

Syaiful. 2009. Unsur Hara Tanaman. http://scrib.com/doc/29584818/ UNSUR-HARA-TANAMAN. Di akses tanggal 27 Juli 2010.

Wididana, G. N. 1998. Daur Ulang Limbah Organik Dengan Teknologi Effective (EM). Penerbit IPSA. Jakarta. 